\title{
Tracking the constraints on a grammaticalizing perfect(ive)
}

\author{
Mary T. Copple (Kansas State University)
}

The grammaticalization of perfects from resultative to perfective has been much researched (Harris 1982, Bybee et al. 1994); however, debate continues over how extension to perfective contexts occurs (Squartini and Bertinetto 1995). In varieties of contemporary Peninsular Spanish, the Present Perfect (PP) competes with the Preterit in perfective contexts, and exhibits advanced grammaticalization as it is well established in hodiernal temporal reference (Schwenter 1994, Serrano 1994). Comparison of variation patterns in Peninsular and Mexican Spanish suggests that indeterminate temporal reference (perfective, but not temporally specified) is the context most susceptible to further perfective grammaticalization (Schwenter and Torres Cacoullos 2008).

This study examines PP grammaticalization from a diachronic, variationist perspective, employing PP and Preterit data from dramatic texts of three different centuries $\left(15^{\text {th }}: \mathrm{N}=638\right.$, $17^{\text {th }}: \mathrm{N}=1546$, and $19^{\text {th }}: \mathrm{N}=1502$ ). The $15^{\text {th }}$ century PP is characterized as a resultative/emerging perfect. Extension to non-specified contexts (where temporal reference is either irrelevant or indeterminate) is concentrated in semantic classes associated with resultative use, while the PP in immediately preceding temporal reference has developed a "hot news" function.

In the $17^{\text {th }}$ century, the PP truly becomes established as a perfect, extending to all semantic verb classes in non-specified contexts where temporal reference is irrelevant, with an accompanying rise in frequency relative to the Preterit. The PP also extends its use in temporally indeterminate contexts as those contexts favor in the $17^{\text {th }}$ century Variable-Rule Analysis. In the $19^{\text {th }}$ century, the PP continues its extension into perfective and temporally specified contexts as hodiernal contexts favor selection of the PP.

It is concluded that the non-specified temporal reference contexts play a special role in the PP's grammaticalization. The temporally irrelevant PP function helps to solidify the event focus of the "hot news" perfect, while the indeterminate function relaxes the restrictions of current relevance by strengthening the PP's association with perfectivity.

\section{References}

Bybee, Joan, Perkins, Revere \& Pagliuca, William. 1994. The evolution of grammar: The grammaticalization of tense, aspect and modality in the languages of the world. Chicago: University of Chicago Press.

Harris, Martin. 1982. The 'past simple' and 'present perfect' in Romance. In Martin Harris \& Nigel Vincent (eds.), Studies in the Romance verb, 42-70. London: Croom Helm.

Schwenter, Scott A. 1994. The grammaticalization of an anterior in progress: evidence from a Peninsular Spanish dialect. Studies in Language 18:71-111.

Schwenter, Scott A. \& Torres Cacoullos, Rena. 2008. Defaults and indeterminacy in temporal grammaticalization: The 'perfect' road to perfective. Language Variation and Change 20:1-39.

Serrano, María José. 1994. Del pretérito indefinido al pretérito perfecto: Un caso de cambio y gramaticalización en el español de Canarias y Madrid. Linguística española actual 16:37-57.

Squartini, Mario \& Bertinetto, Pier Marco. 1995. The simple and compound past in romance languages. Quaderni del Laboratorio di Linguistica 9:219-240. 